\title{
A newborn with a genital prolapse
}

\author{
D M Borensztajn, ${ }^{1}$ K Haasnoot, ${ }^{1}$ G J Blok, ${ }^{1}$ G M A Beckers²
}

${ }^{1}$ Department of Pediatrics, Medisch Centrum Alkmaar, Alkmaar, The Netherlands

${ }^{2}$ Department of Urology, VUMC Amsterdam, Amsterdam, The Netherlands

Correspondence to D M Borensztajn, dorineb@gmail.com

\section{DESCRIPTION}

We describe a 3-week-old girl with a genital prolapse. She was seen postnatally because a prenatal ultrasound had shown a cystic dilation in the right kidney. Ultrasound showed two duplex kidneys, with hydronephrosis of the upper pole of the right kidney and a ureterocele in the bladder. Antibiotic prophylaxis was started while further investigations were awaited. At 3 weeks of age the patient presented to the emergency department with fever. Physical examination showed a moderately ill girl, with no obvi- ous signs to explain the origin of the fever. Genital examination showed a blue cystic mass extruding from the vulva, most likely a ureterocele (figure 1). Urine culture was positive for Klebsiella oxytoca. Dimercaptosuccinic acidscintigraphy showed an almost non-functioning upper pole of the right kidney. The patient was treated with intravenous antibiotics and made a good recovery. Voiding cystogram showed right-sided vesicoureteral reflux grade one to the lower pole.

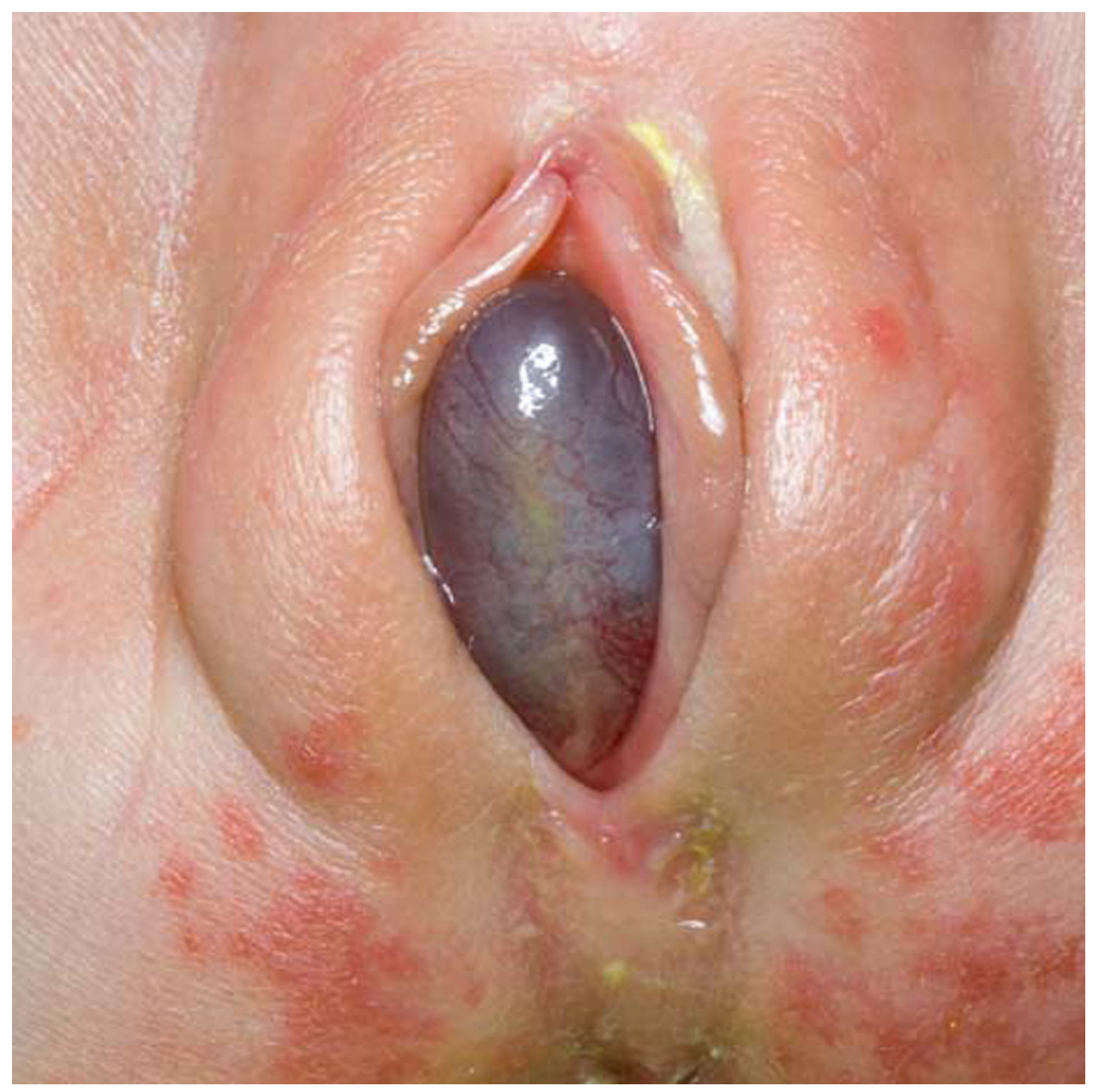

Figure 1 Examination of the genitals of the girl showed a blue cystic mass extruding from the vulva. Ultrasound imaging confirmed the diagnosis of an ectopic ureterocele. A differential diagnosis of, for example, hymen imperforatus, can also be made by ultrasound. 


\section{BMJ Case Reports}

The girl was referred to a paediatric urologist for incision of the ureterocele. At the age of 12 months a resection of the right upper pole will be performed.

A ureterocele is a dilation of the distal ureter that is located within the bladder; if a portion is located at the bladder neck or urethra, it is termed ectopic or a cecoureterocele. Ureteroceles have an incidence of 1:500-1:4000. ${ }^{12}$ However, a ureterocele presenting as a vulval mass is rather rare and occurs in only $5-10 \%$ of all ureteroceles. ${ }^{13}$ When found, it is advisable to rule out other anomalies, such as duplex kidneys, since they frequently (80-90\%) coincide. $^{12}$
Competing interests None.

Patient consent Obtained.

\section{REFERENCES}

1. Decter RM. Renal duplication and fusion anomalies. Pediatr Clin North Am 1997:44:1323-41.

2. Shokeir AA, Nijman RJ. Ureterocele: an ongoing challenge in infancy and childhood. BJU Int 2002;90:777-83.

3. Ilica AT, Kocaoglu M, Bulakbasi N, et al. Prolapsing ectopic ureterocele presenting as a vulval mass in a newborn girl. Diagn Interv Radiol 2008;14:33-4.

This pdf has been created automatically from the final edited text and images.

Copyright 2010 BMJ Publishing Group. All rights reserved. For permission to reuse any of this content visit

http://group.bmj.com/group/rights-licensing/permissions.

BMJ Case Report Fellows may re-use this article for personal use and teaching without any further permission.

Please cite this article as follows (you will need to access the article online to obtain the date of publication).

Borensztajn DM, Haasnoot K, Blok GJ, Beckers GMA. A newborn with a genital prolapse. BMJ Case Reports 2010;10.1136/bcr.08.2010.3280, date of publication

Become a Fellow of BMJ Case Reports today and you can:

- Submit as many cases as you like

Enjoy fast sympathetic peer review and rapid publication of accepted articles

Access all the published articles

Re-use any of the published material for personal use and teaching without further permission

For information on Institutional Fellowships contact consortiasales@bmjgroup.com

Visit casereports.bmj.com for more articles like this and to become a Fellow 